\title{
Cadmium impact on the phytotoxicity of lead to spring barley Hordeum vulgare
}

\author{
Žaltauskaitè J.* and Mikalaikevičiūtè L. \\ Department of Environmental Sciences, Vytautas Magnus University, Vileikos 8-223, LT-44404 Kaunas, Lithuania \\ Received: 03/04/2018, Accepted: 06/05/2019, Available online: 10/05/2019 \\ *to whom all correspondence should be addressed: e-mail: jurate.zaltauskaite@vdu.lt
}

https://doi.org/10.30955/gnj.002703

\begin{abstract}
The aim of the study was to determine cadmium influence on the lead phytotoxicity to spring barley (Hordeum vulgare L.). The seedlings of $H$. vulgare were treated with single $\mathrm{Pb}$ (ranging from 0.1 to $100 \mathrm{mg} \mathrm{l}^{-1}$ ) and $\mathrm{Pb}$ mixture with $\mathrm{Cd}$. Plant biomass production, physiological response, induction of oxidative damage and metals accumulation in roots and shoots were evaluated. Single $\mathrm{Pb}$ and under the presence of cadmium impaired the growth of $H$. vulgare, altered the content of photosynthetic pigments and induced lipid peroxidation. The addition of $\mathrm{Cd}$ to the $\mathrm{Pb}$ treatments has led to additive or synergistic effects on $H$. vulgare shoot and root dry weight, oxidative damage and increased bioaccumulation. The interactive effect of these metals on the content of photosynthetic pigments was concentration range dependent. Additivity was detected when $H$. vulgare were exposed to low concentrations of $\mathrm{Cd}$ and $\mathrm{Pb}$ and high concentrations of these metals had lower than additive effect.
\end{abstract}

Keywords: Accumulation, barley, cadmium, interaction, lead, oxidative stress.

\section{Introduction}

Heavy metals pollution of soils is considered as one of the most serious problems worldwide because these elements are toxic, not biodegradable and can be incorporated into the food chain. Heavy metals have received particular attention in toxicity studies analysing their effects on plants, though the majority of these studies focus on the possible adverse effects of single metal exposure, not mixtures (Clemens, 2006; Kopittke et al., 2010; Gallego et al., 2012). Since agricultural plants are simultaneously exposed to various pollutants, such as pesticides, heavy metals, fertilizers etc., it is important to investigate the combined effects of pollutants mixtures impact on agricultural plants.

Lead $(\mathrm{Pb})$ and cadmium $(\mathrm{Cd})$ are non-essential metals and they could be found in relatively large amounts in agricultural soils. The main sources of these metals are mining, industrial processes, atmospheric deposition, fertilizers and pesticides application. $\mathrm{Pb}$ is non-redox active metal and can bind strongly to amino acids, enzymes, DNA and RNA and it inhibits root growth, photosynthesis, disturbs water balance (Larbi et al., 2002; Sharma and Dubey, 2005). Lead is extremely phytotoxic and the median toxic concentration is c. $1 \mu \mathrm{M}$ (Kopittke et al., 2010). Despite low Pb solubility and strong interaction with soil particles, elevated $\mathrm{Pb}$ levels are usually recorded in plants growing near roads or in industrial areas (Shadid et al., 2017). Cd is also strongly phytotoxic and causes severe biochemical, physiological and morphological effects. Cd inhibits the growth, alters the functionality of membranes, interferes with enzymatic activities related to photosynthesis, disturbs nutrient translocation in plants, induces oxidative stress (Sandalio et al., 2001; López-Millán et al., 2009).

As $\mathrm{Cd}$ and $\mathrm{Pb}$ are usually found simultaneously in the soils and they could be uptaken by plants as divalent cations (Roth, 2006; Sharma and Dubey, 2005), it could lead to joint effects. Metals mixtures were shown to have more profound effects compared to the toxicity observed at exposure to single metal (Versieren et al., 2016). Scientific and regulatory concern over the ecological effects and risks assessment of pollutant mixtures has increased within the last several decades, though the current regulatory risk assessment of chemicals is still based on single toxicity data (Backhaus and Faust, 2012). Joint effects of metal mixtures can result in effect additivity, synergism and antagonism. Additivity often occurs when the components of the mixture affect the same target or have the same mode of action. Synergism may occur due to accelerated bioaccumulation, inhibition of detoxication of one of the component of the mixture or due to increased bioactivation of one of the component of the mixture. In case of antagonism, the observed mixture effect level is lower than predicted by summing the effects for the individual components of the mixture. The predominant responses of metals mixtures were reported to be antagonism and synergism, irrespective of the organisms and environmental compartment (Vijver et al., 2011). The effects of metals mixtures on aquatic and terrestrial plants have been studied extensively, especially $\mathrm{Cd}$ mixtures with essential metals (such as $\mathrm{Cu}$, Zn) (Versieren et al., 2017; Horvat et al., 2007; Qian et al., 
2009; Yan et al., 2015). Montvydienè and Marčiulionienè (2004) have observed that concentrations of $\mathrm{Cd}, \mathrm{Cu}, \mathrm{Cr}$, $\mathrm{Mn}, \mathrm{Pb}, \mathrm{Zn}$ and $\mathrm{Ni}$ in mixtures that caused the same adverse effects to Lepidium sativum and Spirodela polyrrhiza were lower than in single treatments and sometimes the differences reached two orders of magnitude. Interactive effects of non-essentials $\mathrm{Cd}$ and $\mathrm{Pb}$ on crop growth were not analysed while additive or synergistic effects were recorded in aquatic plants (Alonso-Castro et al., 2009; Saygideğer, Doğan, 2004). Though different cadmium and lead bioavailability from environment and similar pathway of uptake may lead to interaction of these metals and joint toxicity could be different compared to single metal toxicity (Clemens, 2006; Sharma and Dubey, 20025). The aim of the study was to determine how cadmium addition can influence lead effects to spring barley (Hordeum vulgare L.). Plant biomass production, physiological response, induction of oxidative damage and metals accumulation were evaluated.

\section{Material and methods}

Spring barley (Hordeum vulgare L.) after seed sterilization was germinated on moisture filter paper in dark at $20 \pm 1{ }^{\circ} \mathrm{C}$ for 3 days. After germination seedlings were grown for five days in hydroponics filled with aerated nutrient solution $\left(0.4 \mathrm{mM} \mathrm{CaCl}_{2}, 0.65 \mathrm{mM} \mathrm{KNO}_{3}, 0.25 \mathrm{mM}\right.$ $\left.\mathrm{MgCl}_{2} * 6 \mathrm{H}_{2} \mathrm{O}, 0.01 \mathrm{mM}\left(\mathrm{NH}_{4}\right)_{2} \mathrm{SO}_{4}, 0.04 \mathrm{mM} \mathrm{NH}_{4} \mathrm{NO}_{3}\right)$. Seedlings were exposed for 5 days to single lead (as $\mathrm{PbSO} 4)$, the tested concentrations were $0.1,1,5,10$ and $100 \mathrm{mgPb} \mathrm{l}^{-1}$. According to the same procedures the experiment with the addition of $\mathrm{Cd}\left(\mathrm{as} \mathrm{CdSO}_{4} \cdot 8 / 3 \mathrm{H}_{2} \mathrm{O}\right)$ was executed. The treatments concentrations were $0.1 \mathrm{~Pb}+0.1 \mathrm{Cd}, 1 \mathrm{~Pb}+1 \mathrm{Cd}, 5 \mathrm{~Pb}+5 \mathrm{Cd}, 10 \mathrm{~Pb}+10 \mathrm{Cd}$ and $100 \mathrm{~Pb}+100 \mathrm{Cd}$, in $\mathrm{mg} \mathrm{l}^{-1}$. Three replicates for each single and joint heavy metal treatment and control were used. The range of the tested metal concentrations was chosen to simulate the levels of these metals as they are found in soil - from uncontaminated, slightly contaminated to severely contaminated (Reimann et al., 2012). The similar $\mathrm{Cd}$ concentrations were tested in other previous studies (Versieren et al., 2017; Žaltauskaitè and Šliumpaitè, 2013ab). The plants during the experiment were from 9th to 11th growth stage according to $\mathrm{BBCH}$ (Meier, 2001). Experiments were carried out in controlled chambers: photoperiod - 14 hours, temperature $-22 \pm 1^{\circ} \mathrm{C}$ at daytime and at $16 \pm 1^{\circ} \mathrm{C}$ at night, relative humidity $-65 \%$, light intensity of $14000 \mathrm{Lx}$.

The following endpoints were measured: plant growth as dry weight, root length, content of photosynthetic pigments (chlorophyll a, b, carotenoids), content of malondialdehyde and metal bioaccumulation. Single $\mathrm{Cd}$ toxicity to Hordeum vulgare was discussed in previous our paper (Žaltauskaitè and Šliumpaitè, 2013a).

Content of chlorophylls ( $a, b)$ and carotenoids was measured spectrofotometrically in $100 \%$ acetone extract (von Wettstein, 1957). Concentration of malondialdehyde (MDA), was used as biomarker of membrane oxidative damage. MDA content was determined by reaction with thiobarbituric acid (Buege and Aust, 1978).

Bioaccumulation of metals was measured in plant roots and shoots. Plant samples were dried for $48 \mathrm{~h}$ at $70^{\circ} \mathrm{C}$ temperature and digested using Milestone Ethos One closed vessel microwave system. Metals concentrations were determined with Shimadzu AA-6800 atomic absorption spectrometer.

Metal interaction in the mixtures was assessed using Abott's formula (Gatidou and Thomaidis, 2007). The expected inhibition of the mixture, expressed as percent $C_{\text {exp }}$, were predicted as follows:

$C_{\mathrm{exp}}=A+B-\left(\frac{A B}{100}\right)$

where $A$ and $B$ are the inhibitions caused by the single metals.

The ratio of inhibition (RI) was calculated as follows:

$\mathrm{RI}=$ observed inhibition $/ \mathrm{C}_{\exp }$

Interaction type was evaluated by comparing RI with 1 . RI values $>1$ indicated synergism; $R=1$ - additivity, $R<1-$ antagonism.

A one-way analysis of variance (ANOVA) was used to assess the concentration effect on estimated endpoints. Significant differences between control and treatments were determined by the Student's t-test and $\mathrm{p}<0.05$ were considered to be significant. Least Significant Difference (LSD) tests were used to evaluate statistically significant differences between the treatments.

\section{Results and discussion}

Exposure to single $\mathrm{Pb}$ had no significant impact on the dry weight of $H$. vulgare shoot (ANOVA, $F=0.72, p=0.62$ ) (Figure 1). The inhibitory effect of $\mathrm{Pb}$ on the root dry weight was observed only at the highest $\mathrm{Pb}$ concentration where the dry weight of root was by $43.25 \%$ lower than in the control. Single Cd impact was more severe to dry weight of $H$. vulgare (Žaltauskaitè and Šliumpaitè, 2013a). Negative impact of $\mathrm{Pb}$ on plant biomass was recorded in several studies, though the impact usually could be denoted as moderate. Lead concentrations up to $2 \mathrm{mM}$ had no significant effect on shoot and root dry weight of Beta vulgaris (Larbi et al., 2002). Significant reduction in shoot biomass production was reported for Sesbania drummondii after exposure to $250 \mathrm{mg} \mathrm{l}^{-1}$ of $\mathrm{Pb}$ (Israr et al., 2011).

The presence of $\mathrm{Cd}$ in the solution resulted in the significant inhibition of shoot and root dry weight (ANOVA, $F_{\text {shoot }}=18.47, F_{\text {root }}=6.35, p<0.01$ ). The dry weight of shoots in the treatments with $\mathrm{Pb}+\mathrm{Cd}$ was by 21.31-68.30\% $(p<0.05)$ lower than that of controls and by $24.84-53.97 \%$ lower than that of single $\mathrm{Pb}$ treatments. The root dry weight was reduced by 16.34-65.31\% after the exposure to the mixture of $\mathrm{Pb}$ and $\mathrm{Cd}$. The results indicated that $\mathrm{Cd}$ amplified the negative impact of $\mathrm{Pb}$ to weight increment and root dry weight has reached up to 
$87.23 \%$ of root dry weight after single treatment with $\mathrm{Pb}$. The addition of $\mathrm{Cd}$ to the $\mathrm{Pb}$ treatments has led to additive or synergistic effects on $H$. vulgare shoot and root dry weight $(\mathrm{RI}>$ or $=1)$.

Similar $\mathrm{Pb}$ interactions with other heavy metals were shown in other studies. Israr et al. (2011) found that single $\mathrm{Pb}$ treatment (250 $\mathrm{mg} \mathrm{l}^{-1}$ ) was less harmful to perennial shrub $S$. drummondii biomass production than $\mathrm{Pb}$ mixtures with $\mathrm{Cu}, \mathrm{Ni}$ and $\mathrm{Zn}$. Binary mixture of $\mathrm{Cd}$ and $\mathrm{Pb}$ had additive interaction on Cucumis sativum shoot growth and greater than additive interaction for root growth (An et al., 2004). Greater $\mathrm{Pb}$ phytotoxicity under the presence of $\mathrm{Cd}$ was also determined to Typha latifolia (AlonsoCastro et al., 2009).

$\mathrm{Pb}$ had a significant effect on the concentrations of photosynthetic pigments (ANOVA, $\mathrm{F}_{\mathrm{chl}}=11.01, \mathrm{~F}_{\mathrm{chl} \mathrm{b}}=$ 5.91, $F_{\text {car }}=3.83, p<0.05$ ) (Figure 2). The responses of both, chlorophyll a and chlorophyll $b$, were of the same pattern. Concentrations of chlorophyll $a$ and chlorophyll $b$ decreased along with $\mathrm{Pb}$ concentrations in the solution

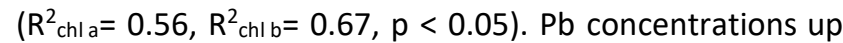
to $10 \mathrm{mg} \mathrm{l}^{-1}$ had minor effect on the concentrations of carotenoids and only in the treatment with $100 \mathrm{mgPb} \mathrm{l}^{-1}$ the concentrations of carotenoids were significantly reduced $(p<0.05)$.
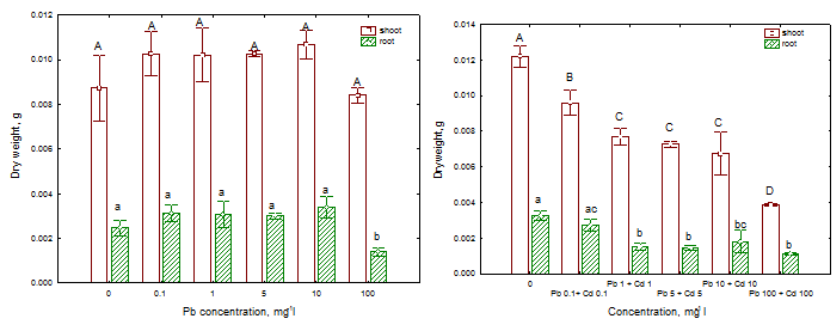

Figure 1. Spring barley $H$. vulgare shoot and root dry weight after exposure to single $\mathrm{Pb}$ and mixture of $\mathrm{Pb}$ and $\mathrm{Cd}$. Different letters (capital letters - shoot, small letters - root) above the columns indicate significant difference $(p<0.05)$ between treatments (LSD test)

The presence of $\mathrm{Cd}$ in the solution reduced negative impact of $\mathrm{Pb}$ on the concentrations of photosynthetic pigments and no significant impact of $\mathrm{Pb}+\mathrm{Cd}$ mixture was found (ANOVA, $F<0.63, p>0.05$ ). The concentrations of photosynthetic pigments in barley treated with both, $\mathrm{Pb}$ and $\mathrm{Cd}$, were only marginally lower than controls. Abotts's formula calculations have showed that addition of $\mathrm{Cd}$ to the $\mathrm{Pb}$ treatment had additive or even antagonistic interaction. Additivity (RI did not differ from 1) was attributed to the mixtures composed of low $\mathrm{Cd}$ and $\mathrm{Pb}$ concentrations (0.1-1 $\mathrm{ml} \mathrm{l}^{-1}$ ) when addition of $\mathrm{Cd}$ has led to a higher impact on the chlorophyll $a, b$ and carotenoids content. Whereas the effects of the mixtures composed of high $\mathrm{Cd}$ and $\mathrm{Pb}$ concentrations were antagonistic $(\mathrm{RI}<1)$ and it may be presumed that $\mathrm{Cd}$ has mitigated negative $\mathrm{Pb}$ effects on the content of photosynthetic pigments.
Only moderate effects of $\mathrm{Pb}$ on the physiological characteristics of other agricultural plants were shown in other studies. $\mathrm{Pb}(10 \mu \mathrm{M}-2 \mathrm{mM})$ had very small effects on the concentrations of photosynthetic pigments in Beta vulgaris (Larbi et al., 2002).
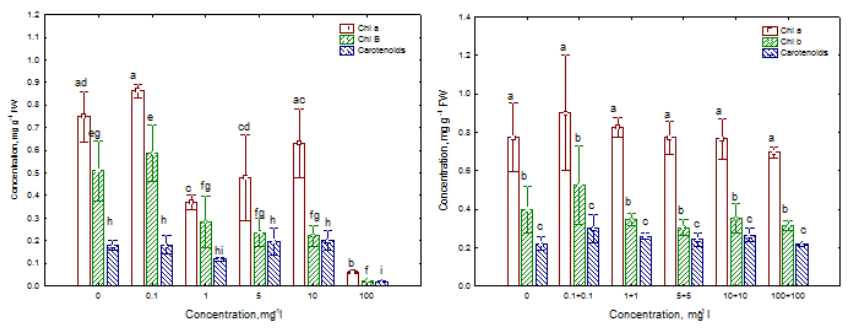

Figure 2. Concentration of photosynthetic pigments (chlorophyll a (chl a), chlorophyll b (chl b), carotenoids) in the leaves of $H$. vulgare exposed to single $\mathrm{Pb}$ and mixture of $\mathrm{Pb}$ and $\mathrm{Cd}$. Different

lowercase letters above the columns indicate significant difference $(p<0.05)$ among the treatments (LSD test), each parameter was evaluated separately

$\mathrm{Pb}$ is non- redox active metal, though it can bind to various enzymes, amino acids and mediate the accumulation of reactive oxygen species and thereby induced lipid peroxidation and oxidative stress (Wang et al., 2008b). Exposure to single $\mathrm{Pb}$ and with $\mathrm{Cd}$ addition has significant effect on MDA concentration in the cells (ANOVA, $\mathrm{F}_{\mathrm{Pb}}=3.54, \mathrm{~F}_{\mathrm{Pb}+\mathrm{Cd}}=4.01, \mathrm{p}<0.05$ ) (Figure 3). Our results revealed that the concentrations of MDA were slightly higher when barleys were exposed to mixture of $\mathrm{Pb}$ and $\mathrm{Cd}$ compared to the levels of MDA after single $\mathrm{Pb}$ exposure. Low levels of $\mathrm{Pb}\left(0.1-1 \mathrm{mg} \mathrm{l}^{-1}\right)$ did not induce the lipid peroxidation though the presence of $\mathrm{Cd}$ in the solutions led to a slightly increase in MDA content. The increase in MDA after single $\mathrm{Pb}$ exposure was observed only in the treatments with $10-100 \mathrm{mgPb} \mathrm{l}^{-1}$, though single $\mathrm{Cd}$ exposure had a significant effect from 10 $\mathrm{mgCd} \mathrm{l}^{-1}$ (Žaltauskaitè and Šliumpaitè, 2013a). Exposure to combine mixture of $\mathrm{Pb}$ and $\mathrm{Cd}$ with $10-100 \mathrm{mg} \mathrm{l}^{-1}$ of each metal in the solution has led to a significant increase in MDA level, 1.87 and 2.52 times, respectively. The induction of lipid peroxidation and MDA accumulation after exposure to single $\mathrm{Pb}$ previously was recorded in tomato and Vicia faba (Wang et al., 2008ab). Higher MDA content after the treatment with Cd imply that these two metals exhibit more than additive effect on the lipid peroxidation and it may lead to higher oxidative damage.

The content of lead in $H$. vulgare roots and shoots was significantly affected by $\mathrm{Pb}$ concentrations (ANOVA, $\mathrm{p}<0.05$ ) (Figure 4). $\mathrm{Pb}$ accumulation in roots was up to 10.36-fold higher than in shoots and increased along with $\mathrm{Pb}$ concentration in the medium $\left(\mathrm{R}^{2}=0.64, \mathrm{p}<0.01\right)$. The accumulation of $\mathrm{Pb}$ in the roots was affected by the presence of $\mathrm{Cd}$ in the solution resulting in the increase in the accumulation of $\mathrm{Pb}$ at the range of high exposure concentrations and slight decrease at the low concentration range. $\mathrm{Pb}$ bioconcentrations in the roots increased along with $\mathrm{Pb}$ concentrations in the mixture of $\mathrm{Pb}$ and $\mathrm{Cd}\left(\mathrm{R}^{2}=0.89, \mathrm{p}<0.01\right)$. 


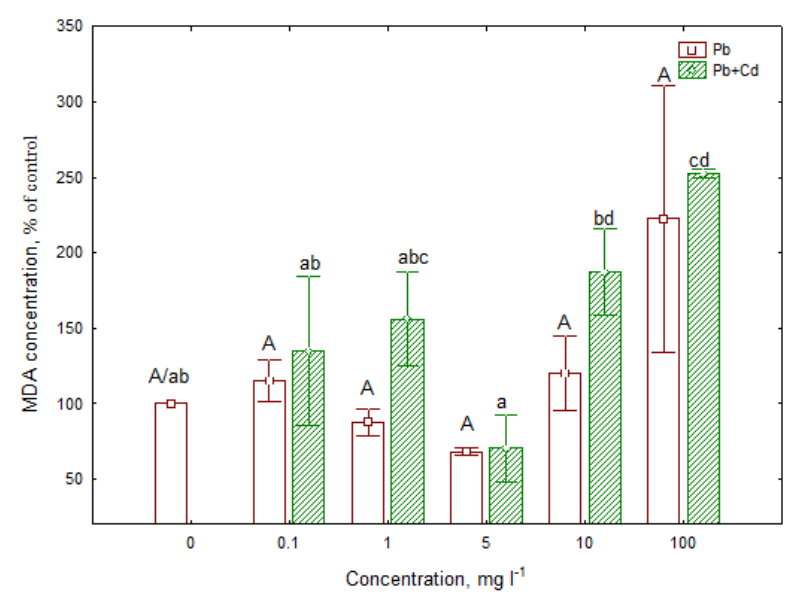

Figure 3. Concentration of MDA in the leaves tissues of $H$. vulgare exposed to single $\mathrm{Pb}$ and mixture of $\mathrm{Pb}$ and $\mathrm{Cd}$. Different letters (capital letters $-\mathrm{Pb}$, small letters $-\mathrm{Pb}+\mathrm{Cd}$ ) above the columns indicate significant difference $(p<0.05)$ between treatments (LSD test)

The translocation of $\mathrm{Pb}$ from roots to shoots have reached up to more than $60 \%$. Higher translocation of $\mathrm{Pb}$ was detected in the treatments with single $\mathrm{Pb}$ (t-test, $\mathrm{p}<0.05$ ) and translocation of $\mathrm{Pb}$ decreased with external metal concentration. The influence of $\mathrm{Cd}$ on the bioconcentrations of $\mathrm{Pb}$ in shoots was analogous as that in the roots, though the difference between $\mathrm{Pb}$ accumulated from the solutions containing single $\mathrm{Pb}$ and the solutions with both metals were somewhat lower. It implies lower $\mathrm{Pb}$ translocation when plants were exposed to a combination of $\mathrm{Cd}$ and $\mathrm{Pb}$. Low $\mathrm{Pb}$ mobility from roots to shoots was also shown in the study conducted by Yoon et al. (2006) with different 17 terrestrial plant species and none of the plant species accumulated $\mathrm{Pb}$ above $1000 \mathrm{mg}$ $\mathrm{kg}^{-1}$ in the shoots, the criteria for a hyperaccumulator (Baker and Brooks, 1989). Larbi et al. (2002) have found that Beta vulgaris exposed to $\mathrm{Pb}$ in the solution had taken only $0.2 \%$ of the total $\mathrm{Pb}$ in nutrient solution. However, Salix viminalis seedlings grown in sewage sludge amended soil tended to accumulate higher concentrations of $\mathrm{Pb}$ in leaves than in roots (Žaltauskaitè et al., 2017).
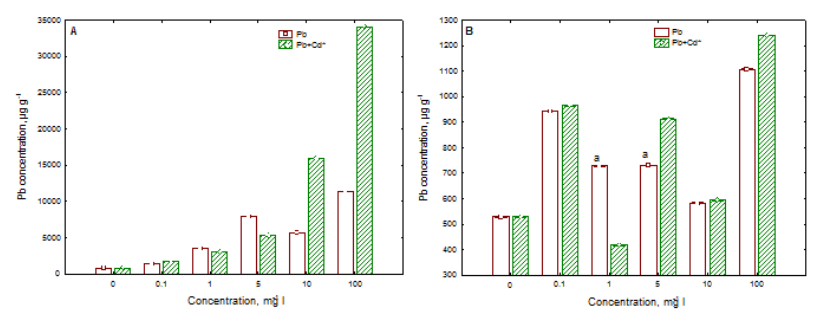

Figure 4. Lead accumulation in roots (A) and shoots (B) of $H$. vulgare exposed to single $\mathrm{Pb}$ and mixture of $\mathrm{Pb}$ and $\mathrm{Cd} .{ }^{*}-$ concentrations $-0.1 \mathrm{~Pb}+0.1 \mathrm{Cd}, 1 \mathrm{~Pb}+1 \mathrm{Cd}, 5 \mathrm{~Pb}+5 \mathrm{Cd}, 10 \mathrm{~Pb}+$ $10 \mathrm{Cd}$ and $100 \mathrm{~Pb}+100 \mathrm{Cd} \mathrm{mg} \mathrm{l}^{-1}$. A - significant difference was found between all the treatments, $B$ - same lsmall letters above the columns indicate nonsignificant difference $(p<0.05)$ between treatments (LSD test)
The higher $\mathrm{Pb}$ accumulation in H.vulgare shoots and roots under the presence of $\mathrm{Cd}$ in the solution are in accordance with the data of biomass production (Figure 1). Cd had additive and synergistic effect on plant biomass and this may be explained by higher $\mathrm{Pb}$ accumulation in the plant.

Very similar or slightly higher $\mathrm{Pb}$ uptake under the presence of $\mathrm{Cu}+\mathrm{Cd}$ was shown in Cucumis sativum (up to $160 \mathrm{mg} \mathrm{Pb} \mathrm{kg}{ }^{-1}$ soil) (An et al., 2004). Our results are in accordance with the other studies showing higher $\mathrm{Pb}$ phytotoxicity under presence of other heavy (Mac Farlane, Burchett, 2002). However, our results contradict to the data reported by Alonso-Castro et al. (2009) who found that $\mathrm{Cd}$ diminished uptake of $\mathrm{Pb}$ by $T$. latifolia.

\section{Conclusions}

Our results indicated that the growth of $H$. vulgare was adversely affected by the single $\mathrm{Pb}$ and its binary mixture with $\mathrm{Cd}$. Single $\mathrm{Pb}$ exposure had moderate effects on biomass of $H$. vulgare, strong adverse effect on the concentrations of photosynthetic pigments and induced lipid peroxidation. The present study shows that $\mathrm{Cd}$ influence on $\mathrm{Pb}$ toxicity to $H$. vulgare is endpoint depending. The addition of $\mathrm{Cd}$ into the solution had additive or synergistic effects on the root and shoot biomass inhibition, induction of lipid peroxidation, bioaccumulation of $\mathrm{Pb}$, though the impact to the concentrations of photosynthetic depending on metal concentration had additive or antagonistic effect.

\section{Acknowledgement}

The study was financed by VMU project No. P-FB-16-03.

\section{References}

Alonso-Castro A.J., Carranza-Álvarez C., Alfaro-De la Torre M.C., Chávez-Guerrero L. and García-De la Cruz. (2009), Removal and accumualtion of cadmium and lead by Typha latifolia exposed to single and mixed metal solutions. Archives of Environmental Contamination and Toxicology, 57, 688-696.

An Y.-J., Kim Y.-M., Kwon T.-I. and Jeong S-W. (2004), Combined effects of copper, cadmium, and lead upon Cucumis sativus growth and bioaccumulation. Science of the Total Environment, 326, 85-93.

Backhaus T. and Faust M. (2012), Predictive environmental risk assessment of chemical mixtures: a conceptual framework. Environmental Science and Technology, 46, 2564-2573.

Baker A.J.M. and Brooks R.R. (1989), Terrestrial higher plants which hyperaccumulate metallic elements-a review of their distribution, ecology and phytochemistry. Biorecovery, 1, 81-126.

Buege J.A. and Aust S.D. (1978), Microsomal lipid peroxidation, Methods in Enzymology, 52, 302-310.

Clemens S. (2006), Toxic metal accumulation, responses to exposure and mechanisms of tolerance in plants. Biochimie, 88, 1707-1719.

Gallego S.M., Pena L.B., Barcia R.A., Azpilicueta C.E., lannone M.F., Rosales E.P., Zawoznik M.S., Groppa M.D. and Benavides M.P. (2012), Unravelling cadmium toxicity and tolerance in plants: insight into regulatory mechanisms. Environmental and Experimental Botany, 83, 22-46.

Gatidou G. and Thomaidis N.S. (2007), Evaluation of single and joint toxic effects of two antifouling biocides, their main 
metabolites and copper using phytoplankton bioassays. Aquatic toxicology, 85, 184-191.

Horvat T., Vidaković-Cifrek Ž., Oreščanin V., Tkalec M. and Pevalek-Kozlina B. (2007), Toxicity assessment of heavy metal mixtures by Lemna minor L., Science of the Total Environment, 384, 229-238.

Israr M., Jewell A., Kumar D. and Sahi S.V. (2011), Interactive effects of lead, copper, nickel and zinc on growth, metal uptake and antioxidative metabolism of Sesbania drummondii, Journal of Hazardous Materials, 186, 1520-1526.

Kopittke P.M., Blamey F.P.C., Asher C.J. and Menzies N.W. (2010), Trace metal phytotoxicity on solution culture: a review. Journal of Experimental Botany, 61, 945-954.

Larbi A., Morales F., Abadía A., Gogorcena Y., Lucena J.J. and Abadía J. (2002), Effects of $\mathrm{Cd}$ and $\mathrm{Pb}$ in sugar beet plants grown in nutrient solution: induced Fe deficiency and growth inhibition. Functional Plant Biology, 29, 1453-1464.

López-Millán A.-F., Sagardoy R., Solanas M., Abadía A. and Abadía J. (2009), Cadmium toxicity in tomato (Lycopersicum esculentum) plants grown in hydroponics. Environmental and Experimental Botany, 65, 376-385.

Mac Farlane G.R. and Burchett M.D. (2002), Toxicity, growth and accumulation relationships of copper, lead and zinc in the grey mangrove Avicennia marina (Forsk.) Vierh. Marine Environmental Research, 54, 65-84.

Meier U. (2001), Growth stages of mono- and dicotyledonous plants. In $\mathrm{BBCH}$ Monographs, Vol. II. Federal Biological Research Centre for Agriculture and Forestry.

Montvydienè D. and Marčiulionienè D. (2004), Assessment of toxic interaction of heavy metals in a multicomponent mixture using Lepidium sativum and Spirodela Polyrrhiza. Environmental Toxicology, 19, 351-358.

Qian H., Li J., Sun L., Chen W., Sheng G.D., Liu W. and Fu Z. (2009), Combined effect of copper and cadmium on Chlorella vulgaris growth and photosynthesis-related gene transcription. Aquatic toxicology, 94, 56-61.

Reimann C., Flem B., Fabian K., Birke M., Ladenberger A., Négrel P., Demetriades A., Hoogewerff J. and The GEMAS Project Team (2012), Lead and lead isotopes in agricultural soils in Europe - The continental perspective. Applied Geochemistry, 27, 532-542.

Roth U., von Roepenack-Lahaye E. and Clemens S. (2006), Proteome changes in Arabidopsis thaliana roots upon exposure to $\mathrm{Cd}^{2+}$. Journal of Experimental Botany, 57, 4003-4013.

Sandalio L.M., Dalurzo H.C., Gómez M., Romero-Puertas M.C. and Del Río L.A. (2001), Cadmium-induced changes in the growth and oxidative metabolism of pea plants. Journal of Experimental Botany, 52, 2115-2126.

Saygideğer S. and Doğan M. (2004), Lead and cadmium accumulation and toxicity in the presence of EDTA in Lemna minor L. and Ceratophyllum demersum L. Bulletin of Environmental Contamination and Toxicology, 73, 182-189.

Shadid M., Dumat C., Khalid S., Schreck E., Xiong T. and Niazi N.K. (2017), Foliar heavy metal uptake, toxicity and detoxication in plants: A comparison of foliar and root metal uptake, Journal of Hazardous Materials, 325, 36-58.

Sharma P. and Dubey R.S. (2005), Lead toxicity in plants, Brazilian Journal of Plant Physiology, 17, 35-52
Versieren L., Evers S., AbdElgawad H., Asard H. and Smolders E. (2017), Mixture toxicity of copper, cadmium, and zinc to barley seedlings is not explained by antioxidant and oxidative stress biomarkers. Environmental Toxicology and Chemistry, 36, 220-230.

Versieren L., Evers S., De Schamphelaere K., Bluist R. and Smolders E. (2016), Mixture toxicity and interactions of copper, nickel, cadmium, and zinc to barley at low effect levels: something from nothing? Environmental Toxicology and Chemistry, 35, 483-2492

Vijver M.G., Elliot E.G., Peijnenburg W.J.G.M. and De Snoo G.R. (2011), Response predictions for organisms water-exposed to metal mixtures: a meta-analysis. Environmental Toxicology and Chemistry, 30, 1482-1487.

Von Wettstein D. (1957), Chlorophyll-lethale und der submik roskopische Formwechsel der Plastiden. Experimental Cell Research, 12, 427-506.

Wang C-R., Wang X-R., Tian Y., Yu H-X., Gu X-Y., Du W-C. and Zhou H. (2008a), Oxidative stress, defence response, and early biomarkers for lead-contaminated soil in Vicia fabia seedlings. Environmental Toxicology and Chemistry, 27, 970-977.

Wang C-R., Wang X., Tian Y., Xue Y., Xu X., Sui X. and Yu H. (2008b), Oxidative stress and potential biomarkers in tomato seedlings subjected to soil lead contamination. Exotoxicology and Environmental Safety, 71, 685-691.

Yan Z., Li X., Chen J. and Tam N F-Y. (2015), Combined toxicity of cadmium and copper in Avicennia marina seedlings and the regulation of exogenous jasmonic acid. Ecotoxicology and Environmental Safety, 113, 124-132.

Yoon J., Xinde C., Zhou Q. and Ma L.Q. (2006), Accumulation of $\mathrm{Pb}, \mathrm{Cu}$, and $\mathrm{Zn}$ in native plants growing on a contaminated Florida site. Science of the Total Environment, 368, 456-464.

Žaltauskaitè J. and Šliumpaitè I. (2013a), Evaluation of toxic effects and bioaccumulation of cadmium and copper in spring barley (Hordeum vulgare L.). Environmental Research, Engineering and Management, 64(2), 51-58.

Žaltauskaitè J. and Šliumpaitè I. (2013b), Single and combined toxicity of copper and cadmium to $\mathrm{H}$. vulgare growth and heavy metal bioaccumulation. E3S Web of Conferences, 1, 15013.

Žaltauskaitè J., Judeikytè S., Sujetovienè G. and Dagiliūtè R. (2017), Sewage sludge application effects to first year willows (Salix viminalis L.) growth and heavy metal bioaccumulation. Waste and Biomass Valorization, 8, 18131818. 